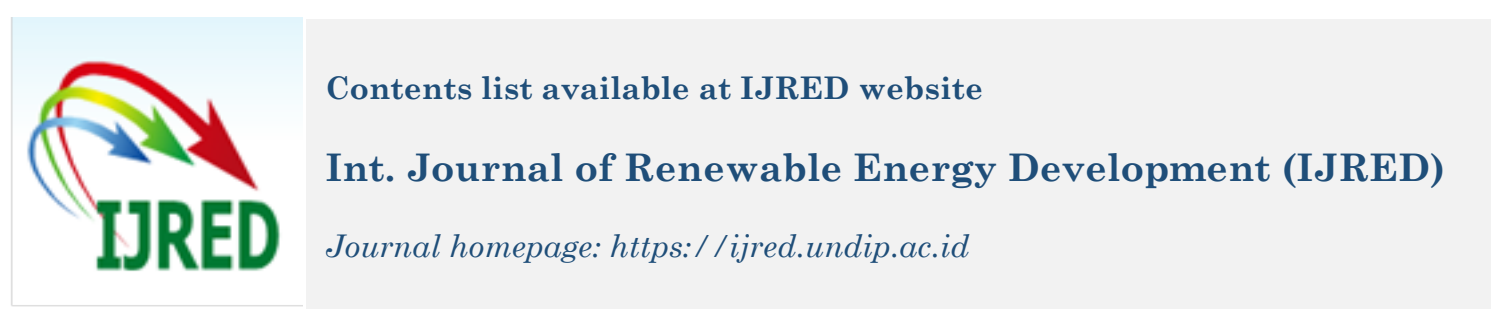

\title{
Hydrodynamic Model and Tidal Current Energy Potential in Lepar Strait, Indonesia
}

\author{
Harman Ajiwibowo ${ }^{*}$ and Munawir Bintang Pratama \\ acean Engineering Department, Institut Teknologi Bandung, Indonesia \\ ${ }^{b}$ School of Engineering, The University of Edinburgh, United Kingdom
}

\begin{abstract}
Previous studies have shown the abundance of tidal energy resources in Indonesia. However, some sites have yet to be considered. The Lepar Strait, for example, is located between Bangka and Lepar Islands. This paper describes a field survey and numerical modelling conducted in the Lepar Strait. The modelling was performed using Delft3D, with the aim of determining potential sites for harvesting tidal current energy and estimate the generated power. In the modelling, the domain decomposition method was employed for model downscaling, allowing grid resolution reaching $130 \times 130 \mathrm{~m}^{2}$, which is sufficient to represent the narrow gaps between tiny islands in the area of interest. The National Bathymetric (Batnas) from the Geospatial Information Agency (BIG) and the International Hydrographic Organization (IHO) tide constituents were applied for the bathymetry and tide elevation boundaries. The comparison between the surveyed and modelled data showed a good agreement. The RMSE and $\mathrm{r}$ for water level are $>0.95$ and $<0.15$, and the RMSE for velocity was $<0.19$. Furthermore, an energetic flow reaching $1.5 \mathrm{~m} / \mathrm{s}$ was found at the Northern part of Lepar Strait, situated at the narrow gaps. The Gorlov Helical Turbine was selected in this study due to shallow water and low mean velocity. In the 2019 model, the power density and power output at the best potential sites were $2,436.94 \mathrm{kWh} / \mathrm{m}^{2}$ and $1,870.41 \mathrm{kWh}$, respectively. This number is higher than those previously found in Kelabat Bay. Nonetheless, it is still far below the currently promising project in Larantuka and Lombok Straits. Future research is recommended, to conduct a detailed field measurement campaign and assess the impact of energy extraction in more detail.
\end{abstract}

Keywords: Renewable Energy; Power Output; Lepar Island; Numerical Model; Tide; Delft3D.

Article History: Received: $2^{\text {nd }}$ March 2021; Revised: $12^{\text {th }}$ July 2021; Accepted: $30^{\text {th }}$ July 2021; Available online: $5^{\text {th }}$ Sept 2021

How to Cite This Article: Ajiwibowo, H., and Pratama, M.B. (2022) Hydrodynamic Model and Tidal Current Energy Potential in Lepar Strait, Indonesia. International Journal of Renewable Energy Development, 11(1),15-25

https://doi.org/10.14710/ijred.2022.37028

\section{Introduction}

Regarding the global action for slowing climate change, nowadays, countries commit to reducing carbon emissions. One of the crucial strategies is substituting conventional energy (derived from oil, gas, and coal) with environmentally friendly sources. Renewable energy is deemed to be a game-changing solution (Gielen et al., 2019). This energy is available in many forms, e.g. bioenergy, solar, geothermal, hydro, wind, and ocean energy (Moomaw et al., 2011). Currently, hydropower still dominates renewable energy generation in 2018, contributing over $60 \%$ of the global value (Ritchie, 2017). However, only a small number of countries possess this resource.

In Indonesia, conventional sources are still dominating the energy mix. In 2025, the contribution of renewable energy is expected to rise to $23 \%$ (IRENA, 2017), creating ample space for renewable energy development. Solar, geothermal, biomass, and wind energy are currently implemented at a commercial level (DEN, 2019). Meanwhile, ocean energy is still struggling with financial viability. The most promising ocean energy is wave and tidal energy. Tidal energy offers more benefits with its predictability and considerable potential (Uihlein \& Magagna, 2016).

Tidal energy is driven by the tide, governed by astronomical gravitational forces. The early generation of tidal energy utilised a barrage to create head differences between two water bodies. The structure then provided gates/channels to circulate the water, consequently rotating the turbine placed in the channels. The most recent advanced technology directly harnesses the kinetic energy of tidal currents using tidal turbines, kites, or other instruments (Uihlein \& Magagna, 2016). The last two decades have seen considerable progress on tidal energy research, such as at the Pentland Firth and Orkney Waters in Scotland, where semi-diurnal tides generate a consistent energetic current that can reach 5 m/s (Neill et al., 2017). In April 2021, the Orbital' O2 Tidal Turbine had commenced operations as a full-scale tidal turbine in Orkney Waters, supplying electricity to 2,000 UK homes (Garanovic, 2021).

Several potential tidal energy sites have been studied in Indonesia (Pratama, 2020). Nusa Tenggara Archipelago is currently the most studied region, especially Lombok

\footnotetext{
* Corresponding author: harman.ajiwibowo17@gmail.com
} 
and Larantuka Straits. Research shows that it has good resources (the flow is over $3 \mathrm{~m} / \mathrm{s}$ ) and studies have been progressing into scrutinising the environmental impact of turbine farms (Firdaus et al., 2019, 2020). Besides these straits, there are some more locations in Nusa Tenggara Archipelago where the high-velocity current is evident, such as Molo, Boleng, and Pantar Straits (ASELI, 2014). Eastern Java, Bali, and the Lombok Islands are separated by narrow straits. Toyopakeh, Badung, Bali, and Madura Straits, located in that region, have also been proven to contain an energetic flow (Amiruddin et al., 2019; Fajar et al., 2014; Kurniawan et al., 2021).

Bangka Island also shows energetic flows at Bangka Strait and Kelabat Bay (Ajiwibowo, Lodiwa, et al., 2017b; Ajiwibowo, Pratama, et al., 2017; Pratama, 2017). Additionally, a strong flow is likely to be observed at Lepar Strait due to its tapered geometry and shallow water. However, there is no research recorded studying its available resources.

Currently, the government directives do not only consider the energy potential in developing marine renewable energy. Isolated islands, especially in the outer area of Indonesia, are currently prioritised for generating electricity from marine energy. At these islands, marine energy may offer a cheaper production cost than conventional energy (Novico et al., 2021). Thus, the authors are motivated to investigate the potential tidal current energy at Lepar Strait. Furthermore, the produced energy may be allocated to Lepar Island, the Sadai region, or the five tiny islands located in the middle of the strait. Similarly, Novico et al. (2021) studied the tidal current energy potential around tiny islands in the Patinti Strait, North Maluku. Numerical modelling using Delft3D was performed in this study. The area of interest is Lepar Strait, in which the potential of tidal current energy is sought. The potential sites and output power will be provided. Moreover, Lepar Strait is within the Sadai Industrial Region at Sadai District, named one of the prioritised industrial regions in the period 2020-2024, targeted to depend on mining, agriculture, maritime, and fisheries industries. The industrial regions must be equipped with an electrical supply where $400 \mathrm{MW}$ is expected to be ready (Pemerintah Kabupaten Bangka Selatan, 2018). Thus, tidal energy may answer the electricity and sustainability demand at the same time.

\section{Methods}

\subsection{Study Location}

Bangka Island is located on the Eastern side of South Sumatra Province. Meanwhile, Lepar Island is at the South-Eastern part of Bangka Island, as shown in Figures 1(a) and 1(b). The study location is the Lepar Strait, situated between Bangka and Lepar Islands, illustrated in Figure 1(c). Administratively, it is part of the South Bangka Regency in the Province of Bangka-Belitung Archipelago (BPS Kabupaten Bangka Selatan, 2020). At the side of Bangka Island, various land uses can be found, including salt ponds. Meanwhile, Lepar Island is dominated by palm tree farms. Sea transport is the main transportation method for commuting between the two islands, from Sadai (at Bangka) to Penutuk Ports (at Lepar).
The Gaspar Strait is located at the North-side of Lepar Island, where the average volume of transport between 2010-2014 is $-2.75 \mathrm{~Sv}\left(10^{6} \mathrm{~m}^{3} / \mathrm{s}\right)$ flowing to the South (to Lepar Strait and the Java Sea) (Anwar et al., 2018). However, this variable is still neglected in this study, dedicating more focus to the tidal current. Natalie et al. (2016) studied the ocean's current energy at Gaspar Strait; the measured ADCP data shows some velocity over $2 \mathrm{~m} / \mathrm{s}$ but this was only observed for a short duration in December. Thus, there is less potential for generating energy. Lepar Strait is expected to contain a more energetic flow due to its narrow width.

Three essential features need to be noted: the Northern, Central, and Southern parts. The widths of each are about 4,3 and $8 \mathrm{~km}$, will be illustrated further in Figure 2(c). The Northern side is occupied by five islands (Tinggi, Mentagor, Lutung, Panjang, and Anakaik Islands), as presented in Figure 1(d) (Sippa Cipta Karya, 2017; Visit Bangka Belitung, 2017), consequently shaping a small cross-section to be passed through by the tidal current.

\subsection{Surveys}

Field surveys were conducted to obtain the required data in the study. Water level and current velocity measurements were carried out in October 2019. The water level was measured at Sadai, as indicated in Figure 1(c) as WL1 (red dot). The observation was prolonged for about 12 hours/day from 1-3 October. Meanwhile, the current velocity was measured using Aanderaa at three locations, noted as CV1 - CV3 (blue dots) in Figures 1(c) and $1(\mathrm{~d})$. The measurement was conducted for two days at each location, taking ten hourly data per day.

Due to the lack of continuity, alternative data was sought. A tide station operated by $B I G$ is available at Sadai Port and can be accessed by contacting the agency. The hourly tides were requested for October 2019. Fundamental analysis of the supplied water level data showed a similar finding to Pamungkas (2018). The tides are of diurnal type, which means that, in a day, there is only one high and low tide, ranging between 0.40 and 1.25 $\mathrm{m}$. $\mathrm{K} 1$ is the dominant constituent with $0.679 \mathrm{~m}$ amplitude (Pamungkas, 2018). No additional data was found for current velocity.

Bathymetry data was also required in this research, and secondary data were used. Since the study aims to provide an initial estimation, the bathymetry survey has not yet been performed. Two public datasets were compared: GEBCO and Batnas. GEBCO is publicly and widely used worldwide (GEBCO Bathymetric Compilation Group 2019, 2019), performing satisfyingly in previous studies (Pratama et al., 2020). Batnas is part of the National Digital Elevation Model (DEMNAS), providing a publicly accessible topography and bathymetry of the Indonesian region (BIG, 2018). The data can be retrieved at www.gebco.net and tides.big.go.id/DEMNAS. The resolutions of GEBCO and Batnas are $470 \times 470$ and 185 $\mathrm{x} 185 \mathrm{~m}^{2}$. Since the distances between Lepar, Lutung, Panjang, Mentagor, and Tinggi Islands are less than 470 $\mathrm{m}$, the GEBCO resolution is not sufficient. Meanwhile, the Batnas dataset is capable of displaying the gaps between the islands. The utilisation of Batnas in the hydrodynamic model showed a good performance in the study of tidal 

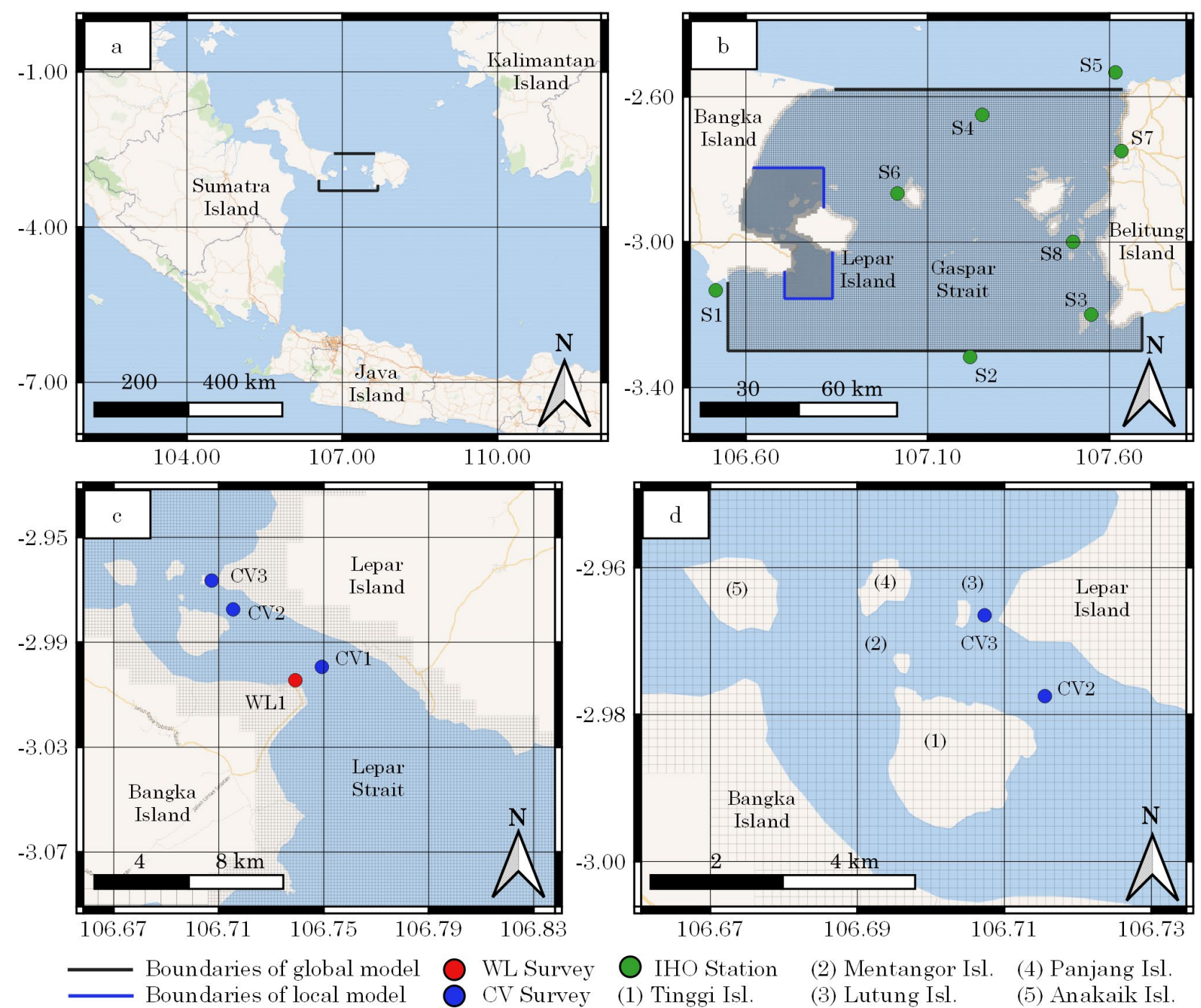

Fig 1. Overview of study location, showing (a) Gaspar Strait, (b) domains of modelling, (c) locations of field measurement activity at Lepar Strait, and (d) islands at the Northern part of Lepar Strait.

energy, wave energy, tsunami, and coastal hydrodynamics (Ajiwibowo \& Pratama, 2017, 2018; Pratama, 2020; Rizal et al., 2019; Takagi et al., 2019).

Previously, Sartika et al. (2018) had conducted a bathymetry survey campaign in December 2017, at Lepar Strait, measuring 92 points representing ten crosssections and one long section using an echo sounder. The measured data showed a good correlation against satellite imagery, obtaining that the maximum depth is between 11 and $16 \mathrm{~m}$. However, the data has yet to be provided to the public.

\subsection{Modelling}

Numerical modelling was performed using Delft3D, an open-source modelling tool developed by Deltares. Delft3D can model the flow, wave, morphology, particle tracking, mixing, water quality, and other phenomena. However, in this research, the model is limited to flow only, driven by the tide. The model does not involve the meteorological forcing and flow induced by density gradients. The shallow water equations govern the model under the Boussinesq assumption. The governing equations consist of the continuity and two momentum conservation equations, given in Eq. (1)-(3) (Deltares, 2014).

$$
\begin{aligned}
\frac{\partial \zeta}{\partial t}+\frac{\partial(\zeta+d) u}{\partial x}+\frac{\partial(\zeta+d) v}{\partial y}= & 0 \\
\frac{\partial u}{\partial t}+u \frac{\partial u}{\partial x}+v \frac{\partial u}{\partial y}+\frac{w}{(\zeta+d)} \frac{\partial u}{\partial \sigma} & =f v-\frac{1}{\rho_{0}} P_{x}+F_{x} \\
& +\frac{1}{(\zeta+d)^{2}} \frac{\partial}{\partial \sigma}\left(v_{V} \frac{\partial u}{\partial \sigma}\right)+M_{x} \\
\frac{\partial v}{\partial t}+u \frac{\partial v}{\partial x}+v \frac{\partial v}{\partial y}+\frac{w}{(\zeta+d)} \frac{\partial v}{\partial \sigma} & =-f u-\frac{1}{\rho_{0}} P_{y}+F_{y} \\
& +\frac{1}{(\zeta+d)^{2}} \frac{\partial}{\partial \sigma}\left(v_{V} \frac{\partial v}{\partial \sigma}\right)+M_{y}
\end{aligned}
$$

where: $\zeta$ is the water level above mean sea level, $x, y$ are the Cartesian coordinates, $u, v, w$ are the horizontal velocity components in the $\mathrm{x}$ and $\mathrm{y}$ directions, $d$ is the water depth, $\sigma$ is the Sigma or scaled vertical coordinate, 
$f$ is the Coriolis parameter, $\rho_{0}$ is the reference density of water, $P_{x}, P_{y}$ are the Gradient hydrostatic pressure in the $\mathrm{x}$ and $\mathrm{y}$ directions, $F_{x}, F_{y}$ are the Radiation stress gradients in the $\mathrm{x}$ and $\mathrm{y}$ directions, $v_{V}$ is the vertical eddy viscosity, and $M_{x}, M_{y}$ are the Momentum sink/source in the $\mathrm{x}$ and $\mathrm{y}$ directions.

The area of interest for the modelling is at Lepar Strait, as shown in Figure 1(c). The modelling was designed in two stages, the global and local model. The coverages were within red lines for the global and red dashed lines for the local domains, as indicated in Figure 2(a). Both models used a rectilinear mesh, placed in spherical and sigma coordinate systems. In vertical space, the velocity is not uniformly distributed. Velocity at the seabed is lower than the upper layers due to the bed roughness (Ajiwibowo, Lodiwa, et al., 2017a). In this research, the depth-averaged model was used and deemed to be sufficient in giving the first estimation of current velocity, offering a lesser computational effort at the same time (Pratama, 2020). Additionally, the depth-averaged velocity data cannot be used to verify the threedimensional velocity.

The global model was built using $650 \times 650 \mathrm{~m}^{2}$ cell resolution, covering $125 \times 80 \mathrm{~km}^{2}(\mathrm{M} \mathrm{x} \mathrm{N}=192 \times 122)$. As shown in Figures 1(b) and 2(a), the Gaspar Strait and the Java Sea are at the Northern and Southern sides. In comparison, Bangka and Belitung Islands are on the Western and Eastern sides. The local model, shown in
Figure 2(b), was designed five times finer than the global model. The resolution is $130 \times 130 \mathrm{~m}^{2}$, with $28 \times 39 \mathrm{~km}^{2}$ coverage ( $\mathrm{M} \times \mathrm{N}=217 \times 302)$. Model downscaling utilises domain decomposition features, providing a smooth refinement and allowing feedback between the parent and child domains. The resolution downscaling was set in odd numbers, and depths at the transition between the models were addressed carefully since a small discrepancy may lead to instability (Rahman \& Venugopal, 2017).

Both global and local models employ the Batnas dataset for bathymetry input with $185 \times 185 \mathrm{~m}^{2}$ resolution. The data were interpolated into the rectilinear grid and resulting bathymetry, as illustrated in Figure 2. Overall, the modelling domain was in shallow water, the maximum depth was about $100 \mathrm{~m}$ and the coasts of Bangka and the Belitung Islands are shallow. Interestingly, the central part of the Lepar Strait is deeper than the Northern and Southern parts, as shown in Figure 2(c) (Hartoko et al., 2019).

Previous studies prescribed measured parameters, such as water level and current velocity, as boundary conditions. However, such data on a global scale in Indonesian Seas is not available. In this study, the measured water level was not imposed as a boundary, but used for validation instead. Alternatively, global tide generators such as NaoTide or TPXO 7.2 are commonly used to generate boundary conditions (Ajiwibowo \&

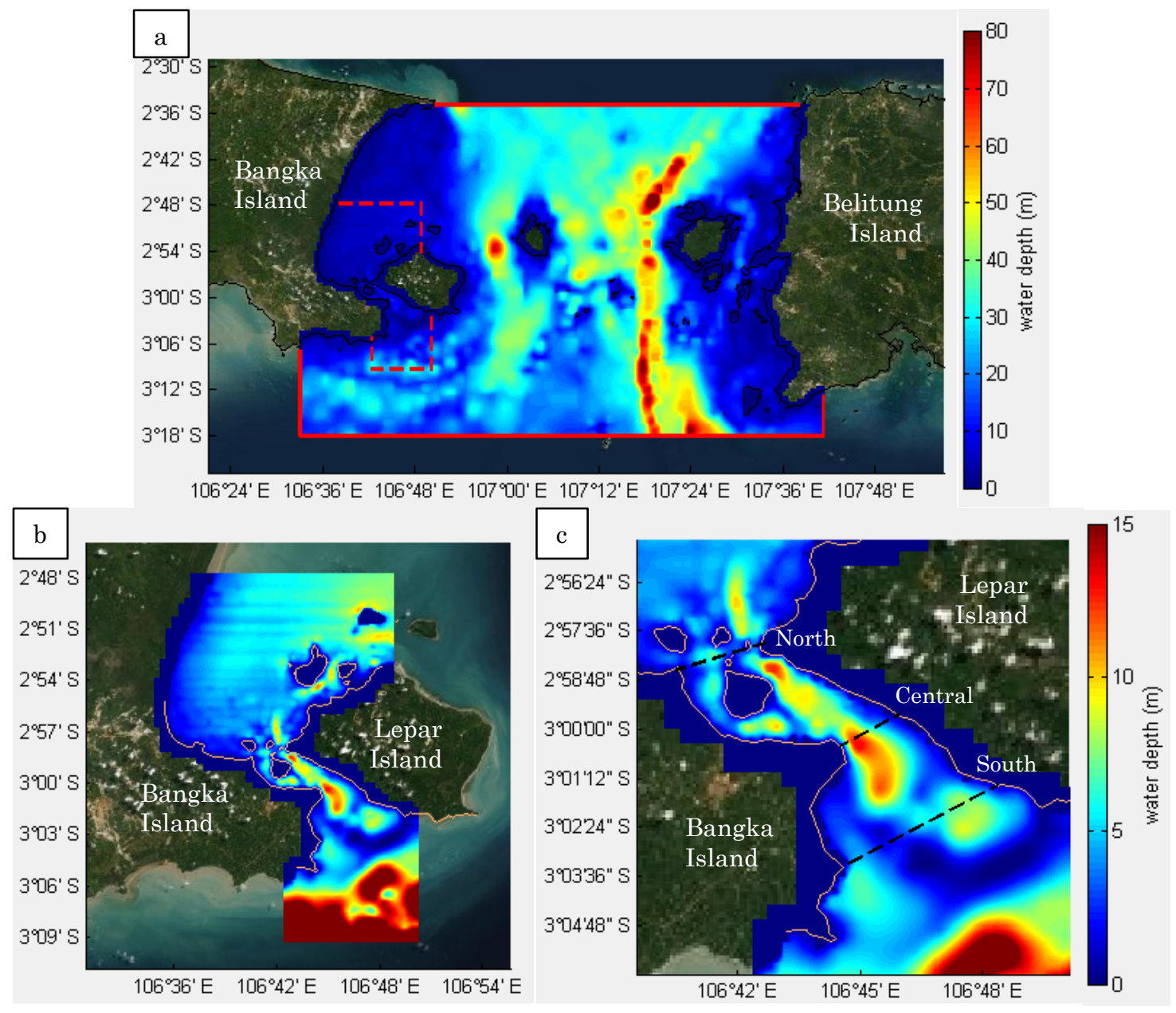

Fig 2 Bathymetry of (a) global model, (b) local model, and details at (c) Lepar Strait generated from Batnas. 
Pratama, 2020; Hariati et al., 2019; Novico et al., 2021; Pratama, 2019).

However, a different approach was used in this study. Since there are eight IHO (International Hydrographic Organization) stations available near the study location, as shown in Figure 1(b), the boundaries were arranged to use the tidal harmonic constituent recorded at the stations as boundary inputs. These data were extracted using Delft-Dashboard (DDB) (Nederhoff et al., 2016). Details of the eight stations are presented in Table 1. Based on their location, only five stations were suitable to be used either as boundary conditions or in model verification. Previous research usually only used IHO stations for model verification (Pratama, 2017). The stations used, had at least five primary constituents: $\mathrm{K} 1, \mathrm{O} 1, \mathrm{P} 1, \mathrm{M} 2$, and $\mathrm{S} 2$.

Ideally, the bed roughness is spatially varying, based on the seabed sediment. Since the seabed map of the area of interest was not found in the public domain, the default $0.02 \mathrm{~m}^{1 / 3} / \mathrm{s}$ manning coefficient was applied as roughness, but other values were also tested in the calibration. Other constants were also applied, such as $1025 \mathrm{~kg} / \mathrm{m}^{3}$ water density, $9.81 \mathrm{~m} / \mathrm{s}^{2}$ gravitational acceleration, and $1 \mathrm{~m}^{2} / \mathrm{s}$ background viscosity. Like previous studies (Pratama, 2020; Rahman \& Venugopal, 2017), Bijvelds's (2001) recommendation for governing time step was adopted. Since the domain was located in shallow water, 0.5 minutes was enough to give the courant number of around 10. At deeper locations, such as Southern Java and Western Sumatra, the same courant number may only be achieved in a much smaller time step, at the cost of a considerable computational effort. In verification, model reliability was quantified using root mean square error (RMSE) and r-Pearson coefficients. The formulas of RMSE and $\mathrm{r}$ are given in Eq. 4 and 5 (de Pablo et al., 2019). Simulation time was set according to the field data, with an extra two days earlier simulation time for the spin-up duration. Furthermore, the model was run for an entire year to test its stability and provide the data required for discussion.

$$
\begin{aligned}
& R M S E=\sqrt{\frac{1}{N} \sum_{i=1}^{N}\left(X_{i}-Y_{i}\right)^{2}} \\
& r=\frac{\sum_{i=1}^{N}\left(X_{i}-\bar{X}_{i}\right)\left(Y_{i}-\bar{Y}_{i}\right)}{\sqrt{\sum_{i=1}^{N}\left(X_{i}-\bar{X}_{i}\right)^{2}} \sqrt{\sum_{i=1}^{N}\left(Y_{i}-\bar{Y}_{i}\right)^{2}}}
\end{aligned}
$$

where: $N$ is the number of samples, $X_{i}$ is the $i^{\text {th }}$ field data, and $Y_{i}$ is the $i^{\text {th }}$ modelled data.

\subsection{Tidal Energy Analysis}

The basics of tidal energy analysis will be described briefly in this section. The expression of power density is given in Eq. 6 (Orhan et al., 2015). This parameter defines the contained power in a tidal flow per square metre and significantly depends on current velocity (cubic). Since this research uses a depth-averaged model, the power density is uniform from the surface to bottom layers. A previous study showed that the bottom layers usually generate a lesser velocity and power density than the upper layer due to bed friction (Ajiwibowo, Lodiwa, et al., 2017a). However, some cases show that the uppermost layer may produce the lowest velocity (Lewis et al., 2017).
$P_{\text {density }}=\sum_{i=1}^{N} \frac{1}{2} \rho U_{i}^{3}$

where: $P_{\text {density }}$ is the power density $\left(\mathrm{kWh} / \mathrm{m}^{2}\right), \quad \rho$ is the water density $\left(\operatorname{ton} / \mathrm{m}^{3}\right)$, and $U$ is the hourly current speed $(\mathrm{m} / \mathrm{s})$.

Equation 7 presents the formula for calculating the tidal turbine's power output (Ajiwibowo, Lodiwa, et al., 2017a). The formula also includes turbine characteristics, namely, power coefficient and frontal area, besides the power density. A higher power coefficient indicates a high energy conversion capacity. The frontal area depends on the turbine dimension.

$P_{\text {output }}=\sum_{i=1}^{N} \frac{1}{2} \rho C_{P} A_{\text {frontal }} U_{i}^{3}$

where: the $\boldsymbol{P}_{\text {output }}$ is the power output $(\mathrm{kWh}), \boldsymbol{C}_{\boldsymbol{p}}$ is the power coefficient, and $\boldsymbol{A}_{\text {frontal }}$ is the frontal area $(\mathrm{m})$.

The tidal turbine placement needs to be considered carefully, ideally at a site with the most substantial flow. However, a site with consistent high velocity is preferred to that with the highest velocity. In this research, the mean value $(\bar{U})$ is used, as expressed in Eq. 8.

$\bar{U}=\frac{\sum_{i=1}^{N} U_{i}}{N}$

\section{Results and Discussion}

\subsection{Model Verification}

To ensure its reliability, the model needs to undergo a verification step, most commonly for water level and current velocity. Initially, the simulated water level is verified against BIG data, at Sadai this is shown as WL1 in Figure 1(c). Five manning coefficients are tested between 0.017 and $0.029 \mathrm{~m}^{1 / 3} / \mathrm{s}$. The errors produced by each coefficient are shown in Table 2 where, generally, the models produce a decent agreement. The lowest RMSE and highest $\mathrm{r}$ are found when using $0.020 \mathrm{~m}^{1 / 3} / \mathrm{s}$, hence this was selected for the subsequent modelling. Manning calibration is also demonstrated in Pratama (2020), similarly showing a less significant impact in reducing the errors.

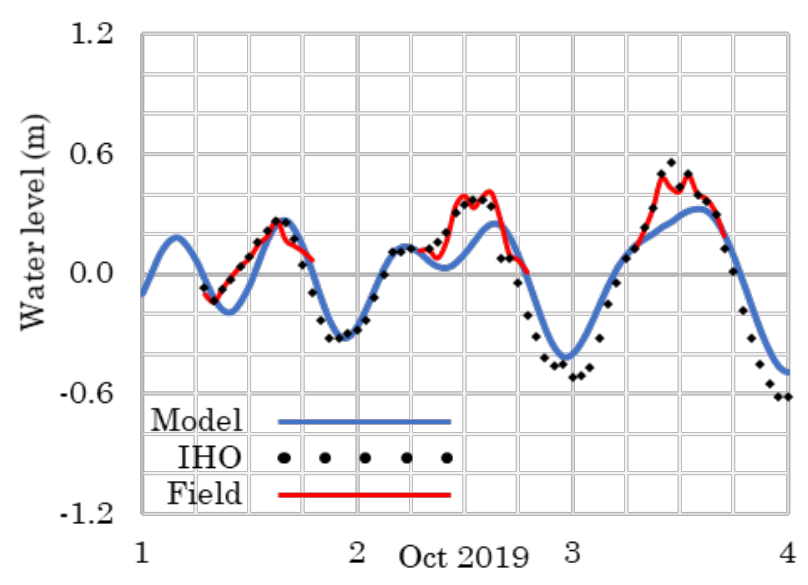

Fig 3 Detailed WL verification at WL1. 
Time-series comparisons between the model, BIG, and surveyed data are provided in Figure 3, where the measured data is almost identical with the BIG observations. The RMSE values between Model - BIG and Model - Survey are 0.135 and 0.176. The comparison against the measured data, results in a more significant error due to the influence of water level fluctuation induced by wind and activity near Sadai Port. In Figure 3, the simulated data underestimates the diurnal low and high tides, anticipated due to more minor diurnal constituents at the boundaries, missing Q1 and S1.

The water level is also verified against data from five IHO stations, shown in Table 2 . The results give satisfying errors; the averages of RMSE and $\mathrm{r}$ are 0.091 and 0.974 , respectively. S1, S2, and S5 are not used since they are located out of the modelling domain. A Time-series comparison of water levels at IHO Stations is presented in Figures 4(a) to 4(f), visually showing a good agreement. Karang Selio (S3) and Akbar Shoal (S4) are used as boundary conditions, showing almost identical amplitude and phase. Meanwhile, the Western side of Belitung Island, where Tanjung Pandan (S7) and Ru Island (S8) are situated, are occupied with tiny islands that are not accommodated in the global model. Thus, errors are more significant. In Figures 4(d) and 4(e), the model underestimates the high tide. Most boundary inputs use constituents less than the nine primary constituents (Wolanski \& Elliott, 2016), expected to be one of the significant factors in the verification performance.

Current velocity verification is presented in Figure 5, conducted at three locations shown in Figure 1(c) as CV1 to CV3 (blue dots). The comparison between the modelled and surveyed data is given in Figure 5. Generally, the model can mimic the surveyed velocity; the trends show a good agreement. At $\mathrm{CV} 2$, the velocity range of the modelled data matches the surveyed data. However, at CV1 and CV3, the model underestimates and overestimates the surveyed velocity. The RMSE for CV1, CV2 and CV3 are 0.13, 0.20, and 0.25, respectively.

Based on the verifications, the model is concluded to be reliable. Nonetheless, it is found that an excellent velocity validation is relatively harder to be achieved than the water level; one factor expected to dominantly influence this is the bathymetry (Pratama et al., 2020).

\subsection{Current Velocity Characterisation}

The spatial distribution of mean depth-averaged velocity at neap (1 October) and spring tides (7 October) are shown in Figure 6. Both time frames indicate that high-velocity intensity is found at the Northern part, occupied by five tiny islands, mean velocity is closing to $0.8 \mathrm{~m} / \mathrm{s}$ at spring tide. The flow gets amplified by these islands. At the Southern part, the mean velocity is around 0.5 to $0.6 \mathrm{~m} / \mathrm{s}$, located near Bangka Island. The mean velocity is 0.7 to $0.8 \mathrm{~m} / \mathrm{s}$ and 0.4 to $0.5 \mathrm{~m} / \mathrm{s}$ at the Northern and Southern parts of the strait using the time frame of one tidal cycle.

Additionally, three sections are introduced at the Northern, Central, and Southern part of Lepar Strait, indicated in Figure 2(c). The cross-sectional views of maximum velocity (from Bangka to Lepar) at spring tide (7 October) are presented in Figure 7. The highest flow intensity reached $1.35 \mathrm{~m} / \mathrm{s}$ at the Northern part, located at a shallow and narrow cross-section near Lepar Island. Meanwhile, at the centre, the velocity is the smallest, less than $0.5 \mathrm{~m} / \mathrm{s}$, due to a deeper channel. In the Southern part, the velocity is varied between Bangka and Lepar sides, influenced by the bathymetry characteristics. Very shallow water near Lepar Island obstructs the flow;

Table 1

\begin{tabular}{cccccc}
\multicolumn{1}{l}{ Detail of IHO stations. } \\
\hline Stations & Locations & Lat (South) & Long (East) & BC & WL Verification \\
\hline S1 & Dapur Island & 3.1333 & 106.5167 & South \& West & na \\
S2 & Ondiepwater Islands & 3.3167 & 107.2167 & South & na \\
S3 & Karang Selio & 3.2000 & 107.5500 & South \& East & $\checkmark$ \\
S4 & Akbar Shoal & 2.6500 & 107.2500 & North & $\checkmark$ \\
S5 & Lengkuas Island & 2.5333 & 107.6167 & North & na \\
S6 & Liat Island & 2.8666 & 107.0167 & - & $\checkmark$ \\
S7 & Tanjung Pandan & 2.7500 & 107.6333 & - & $\checkmark$ \\
S8 & Pulau Ru & 3.0000 & 107.5000 & - & $\checkmark$
\end{tabular}

BC: Boundary condition(s); na = not available

Table 2

Summary of WL verification at WL1 and IHO Stations.

\begin{tabular}{cccccccccccc}
\hline & \multicolumn{3}{c}{$\begin{array}{c}\text { WL verification at WL1 (Sadai) } \\
\text { Errors }\end{array}$} & \multicolumn{3}{c}{ [Sensitivity of Manning Coefficient $\mathrm{m}$ 1/3/s] } & \multicolumn{5}{c}{$\begin{array}{c}\text { WL verification at IHO Stations } \\
\text { (Manning 0.020) }\end{array}$} \\
\hline & 0.017 & 0.020 & 0.023 & 0.026 & 0.029 & $\mathrm{~S} 3$ & $\mathrm{~S} 4$ & $\mathrm{~S} 6$ & $\mathrm{~S} 7$ & $\mathrm{~S} 8$ \\
$\mathrm{RMSE}$ & 0.151 & 0.135 & 0.166 & 0.175 & 0.185 & 0.044 & 0.048 & 0.102 & 0.143 & 0.119 \\
$\mathrm{r}$ & 0.942 & 0.961 & 0.928 & 0.919 & 0.909 & 0.993 & 0.995 & 0.975 & 0.955 & 0.954 \\
\hline
\end{tabular}



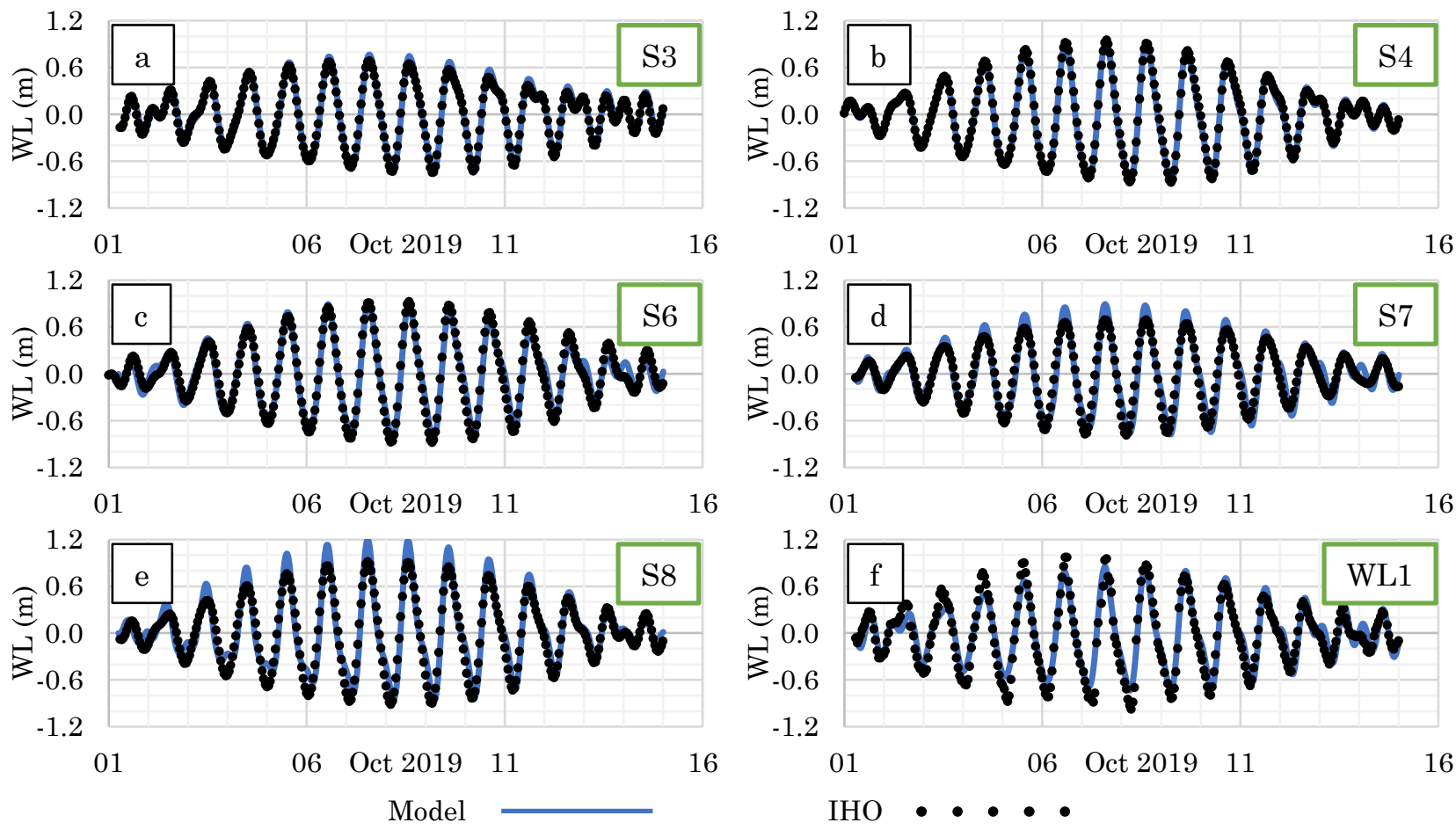

Fig 4 Water level (WL) verification at (a-f) S3, S4, S6, S7, S8, and WL1, respectively.
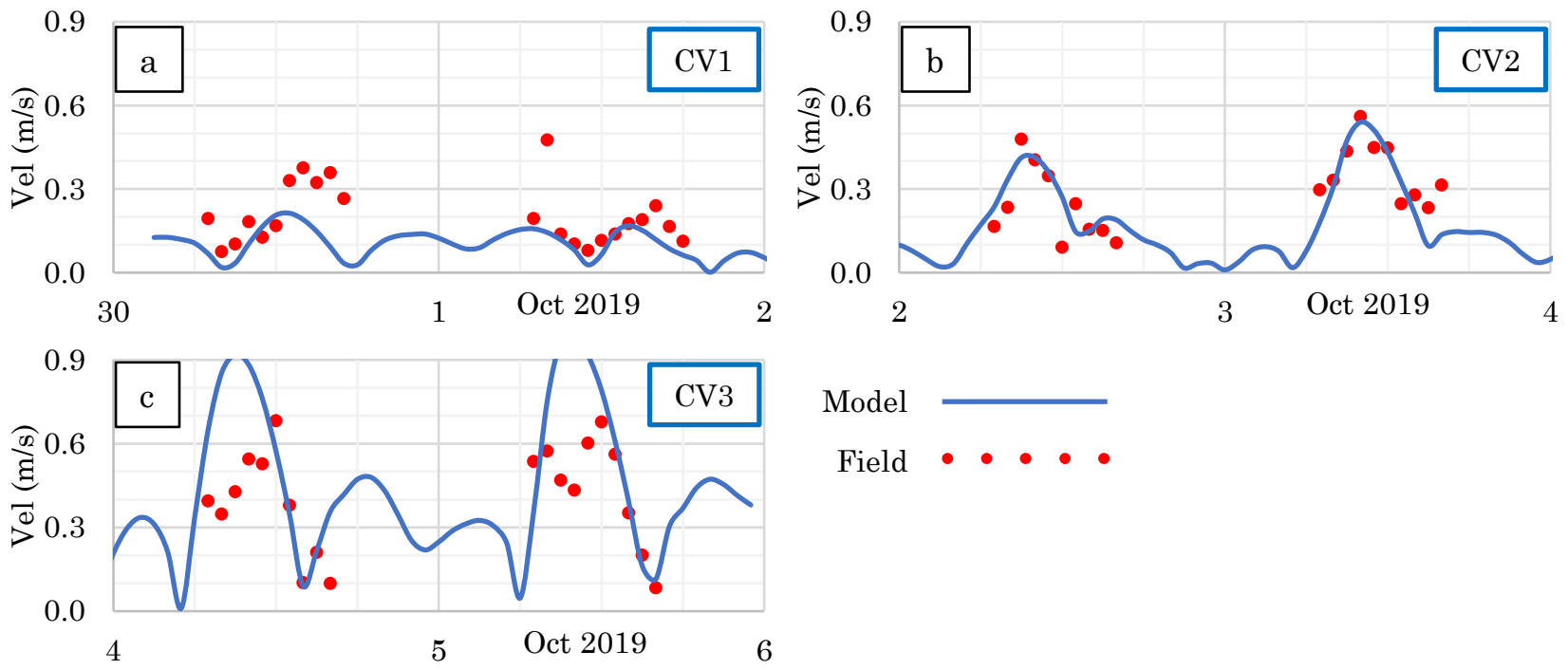

Fig 5 Current velocity verification at (a-c) CV1, CV2, and CV3, respectively.

consequently, flow is accumulated at a basin near Bangka Island, reaching $0.75 \mathrm{~m} / \mathrm{s}$.

The Northern part of Lepar Strait shows a potential current velocity for generating tidal energy, although the tide type is mesotidal or medium tidal range (2 to $4 \mathrm{~m}$ ) (Wolanski \& Elliott, 2016). Figure 8 provides the spatial velocity at the area of interest at spring tide, observed at high, slack-ebb, low, and slack-flood tides. The high velocity is observed only at high and ebb tides; each shows nearly 1.5 and $1.0 \mathrm{~m} / \mathrm{s}$ peak velocity. These energetic sites are located at three narrow channels, named sites A, B, and $\mathrm{C}$, as shown in Figure 8. In contrast, the velocity significantly declines at Slack water, both at ebb and flood.
However, the energetic sites are still capable of producing a velocity of around $0.5 \mathrm{~m} / \mathrm{s}$.

Table 3 provides the detail of sites $\mathrm{A}, \mathrm{B}$, and $\mathrm{C}$. The mean and maximum velocity of each site in 2019 is supplied. These two parameters had been used to identify the energetic spot in previous studies (Ajiwibowo, Lodiwa, et al., 2017a; Novico et al., 2021). The highest velocity at site $A$ is averaged and peaked at 0.66 and $1.55 \mathrm{~m} / \mathrm{s}$, respectively. Site B is only about $10 \%$ lower than the values at site $\mathrm{A}$. Meanwhile, site $\mathrm{C}$ is far below the other two sites. At these three sites, the hourly velocity surpasses the mean value around $48.2 \%-49.2 \%$ in a year. 

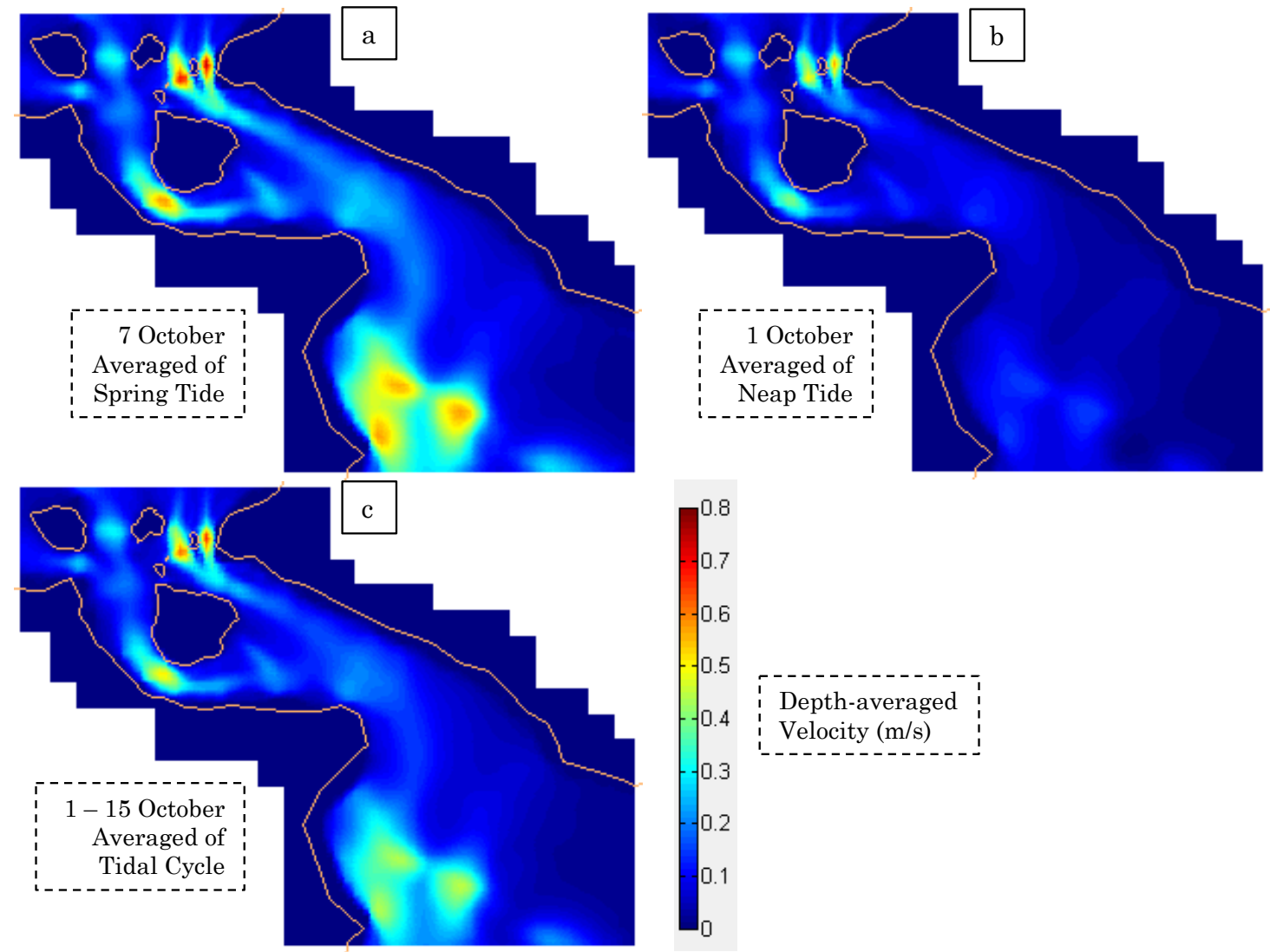

Fig 6 Spatial distributions of mean DAV (depth-averaged velocity) at (a) spring, (b) neap, and (c) one tidal cycle in Lepar Strait.

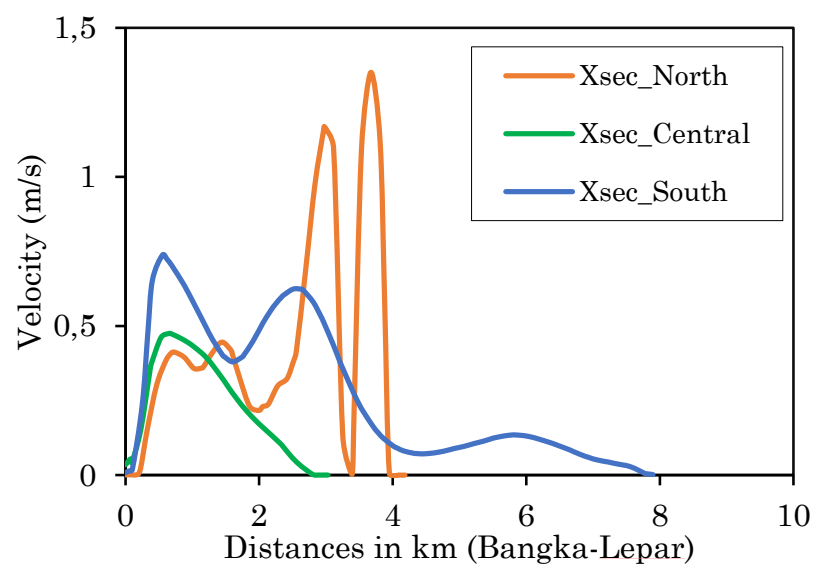

Fig 7 Flow speed passing three cross-sections.

\subsection{Power Calculation}

Theoretical power, defined as annual power density (per 1 $\mathrm{m}^{2}$ of water column), is $2,436.94 \mathrm{kWh} / \mathrm{m}^{2}$ at site A, $1,719.81 \mathrm{kWh} / \mathrm{m}^{2}$ at site B, and only $1,017.68 \mathrm{kWh} / \mathrm{m}^{2}$ at site C. The formula for the annual power is given in Eq. 6 . The model is depth-averaged, neglecting the vertical variation of the current. This vertical variation follows a logarithmic and power law, as described in Lewis et al. (2017). Theoretically, the lowest velocity is obtained at the lowermost layer, while the highest value is evident at the surface. A three-dimensional model is capable of mimicking these phenomena, as demonstrated in Ajiwibowo, Lodiwa, et al. (2017a) and Ajiwibowo, Pratama, et al. (2017). However, the surface velocity at certain times fluctuates out of the logarithmic and the power profile (Lewis et al., 2017). Thus, when the water depth is adequate, the tidal turbine is positioned a few metres (about $5 \mathrm{~m}$ ) below the lower astronomical tide to be exposed by the highest velocity, also to accommodate vertical space for navigational activities.

Table 3 provides the estimation of annual technical power. The technical power is defined as the power output considering the deployed turbine's technological limitation, calculated using Eq. 7. Due to the lower mean velocity and very shallow water $(<3 \mathrm{~m})$, the Gorlov Helical Turbine (GHT) is proposed (SEI, 2005). Based on the literature, the turbine's diameter and length are 1.0 and $2.5 \mathrm{~m}$, resulting in a frontal area of $2.5 \mathrm{~m}^{2}$. To be accommodated at the potential shallow sites, the turbine is installed horizontally. Additionally, the total efficiency is $31.5 \%$, and the cut-in-speed is $0.5 \mathrm{~m} / \mathrm{s}$ (Ajiwibowo, Pratama, et al., 2017). The cut-in speed is lower than the mean velocity at sites $A$ and $B$, which allows the instrument to operate over $50 \%$ of the time. Given this parameter, the annual technical power of one GHT turbine at sites $\mathrm{A}, \mathrm{B}$, and $\mathrm{C}$ is $1,870.41,1,299.45$, and $741.11 \mathrm{kWh}$, respectively. However, the real numbers might be less since the performed power calculation is under various assumptions, such as a constant power coefficient and neglecting the flow field change and turbine hydrodynamic responses. 


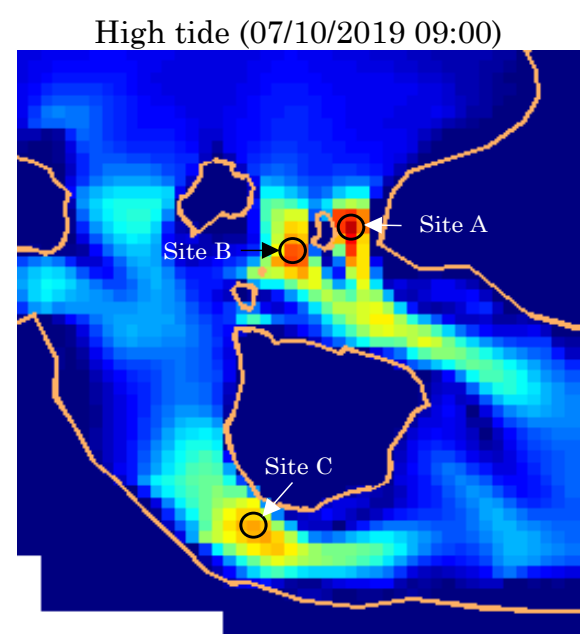

Low tide (08/10/2019 00:00)

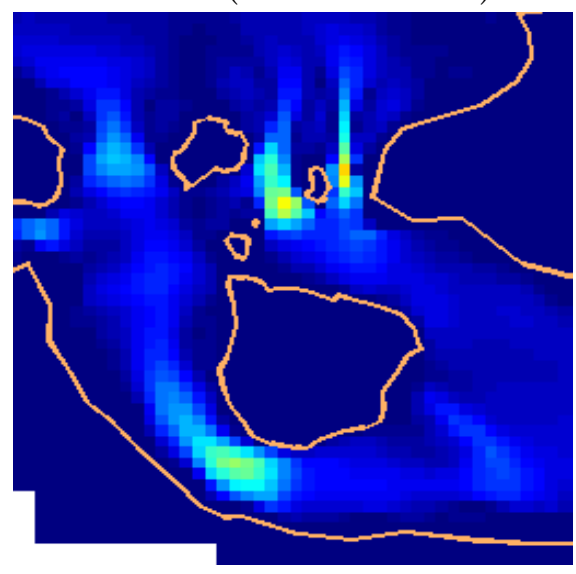

Slack water-Ebb (07/10/2019 18:00)

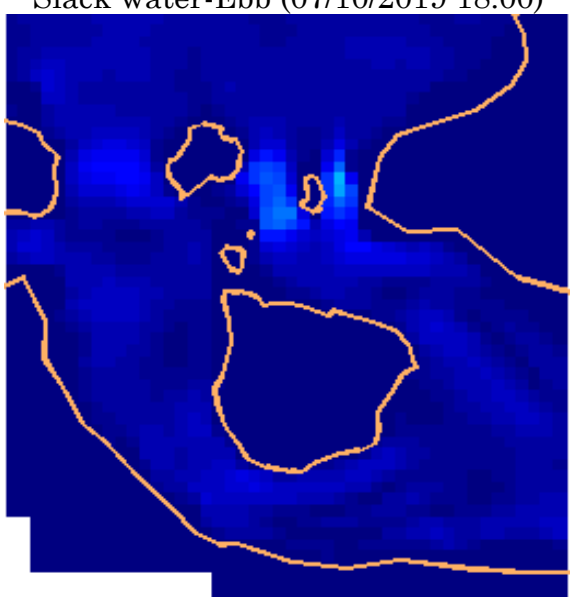

Slack water-Flood (08/10/2019 03:00)

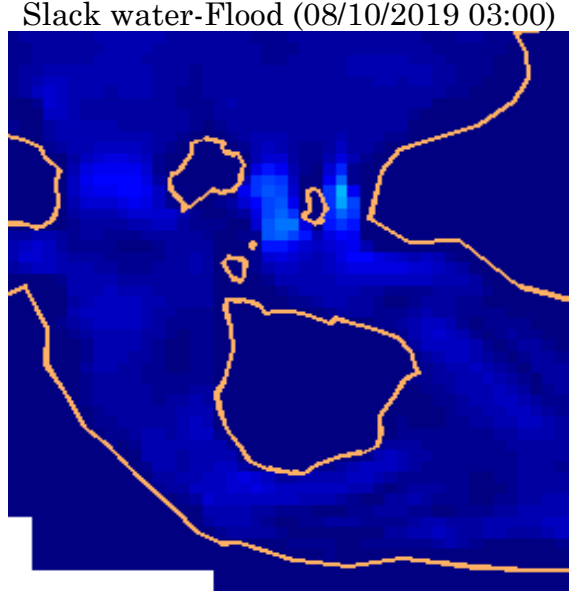

Depth

Averaged

Velocity -

$\operatorname{DAV}(\mathrm{m} / \mathrm{s})$

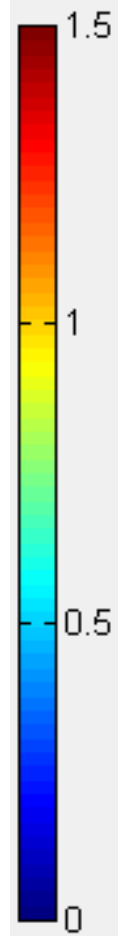

Fig 8 Spatial distributions of DAV at high, low, and slack (spring) tides at the Northern Lepar Strait.

Table 3

Details of potential sites (velocity and power).

\begin{tabular}{ccccccccc} 
Sites & Lat (South) & Long (East) & $\begin{array}{c}\text { Depth } \\
(\mathrm{m})\end{array}$ & $\begin{array}{c}\text { Mean } \\
\text { Velocity } \\
(\mathrm{m} / \mathrm{s})\end{array}$ & $\begin{array}{c}\text { Max } \\
\text { Velocity } \\
(\mathrm{m} / \mathrm{s})\end{array}$ & $\begin{array}{c}\text { \% of Higher } \\
\text { Velocity a } \\
(\%)\end{array}$ & $\begin{array}{c}\text { Theoretical } \\
\text { Power } \\
\left(\mathrm{kWh} / \mathrm{m}^{2}\right)\end{array}$ & $\begin{array}{c}\text { Technical } \\
\text { Power } \\
(\mathrm{kWh})\end{array}$ \\
\hline $\mathrm{A}$ & 2.9657 & 106.7066 & 2.62 & 0.66 & 1.55 & 48.22 & $2,436.94$ & $1,870.41$ \\
$\mathrm{~B}$ & 2.9681 & 106.7006 & 2.16 & 0.58 & 1.45 & 49.20 & $1,719.81$ & $1,299.45$ \\
$\mathrm{C}$ & 2.9969 & 106.6958 & 2.63 & 0.48 & 1.19 & 49.22 & $1,017.68$ & 741.11 \\
\hline
\end{tabular}

a Percentage of hourly velocity which is larger than the mean velocity during a year (2019).

\subsection{Comparison with Other Sites and Limitations}

Around Bangka Island, two other sites were previously studied for tidal current energy, Bangka Strait and Kelabat Bay. At those sites, the mean velocity is below 0.5 $\mathrm{m} / \mathrm{s}$; however, there is a deeper water depth (Ajiwibowo, Lodiwa, et al., 2017b; Ajiwibowo, Pratama, et al., 2017). The maximum output energy per one GHT turbine in Kelabat Bay is $329.71 \mathrm{kWh}$, where the velocity is averaged at $0.37 \mathrm{~m} / \mathrm{s}$. Hence, Lepar Strait is more suitable for GHT applications. Meanwhile, in Bangka Strait, the mean velocity is below $0.5 \mathrm{~m} / \mathrm{s}$ and due to deeper water, it can accommodate the Verdant KHPS Turbine with a higher efficiency (36.1\%).

Furthermore, with respect to sites such as Larantuka, Lombok, Alas, and Sunda Straits, the energy potential in
Lepar Strait is significantly smaller, resulting in lower financial viability (Ajiwibowo, Lodiwa, et al., 2017a; Firdaus et al., 2019; Orhan et al., 2016; Pratama et al., 2020). Nevertheless, for an isolated island where conventional energy is also unviable, the implementation of tidal energy is becoming more promising.

This study is limited to the preliminary estimation of tidal current energy potential in the Lepar Strait. Future research is recommended to conduct an in-depth field survey to obtain an accurate bathymetric map, tidal elevation, and tidal current at the strait, especially at the tiny spaces between the islands. The impact of tidal energy extraction also needs to be studied. Previous studies indicate that the tidal farms may change the regional velocity field (Firdaus et al., 2020), consequently influencing sediment transport (Pratama, 2020). 
Additionally, other forcing, such as wind and waves may be imposed in the model, which may generate a $3 \%$ to $10 \%$ velocity increment (Natalie et al., 2016). In 2019, the average wind speed was $3.6 \mathrm{~m} / \mathrm{s}$ and peaked at $7.9 \mathrm{~m} / \mathrm{s}$ (ECMWF, 2021). While in 2016, the Wavewatch III model of Badan Informasi Geospasial (0.125 x $0.125^{\circ}$ resolution) showed that the average significant wave height and mean period around the area is $0.26 \mathrm{~m}$ and 3.3 seconds (BIG, 2021). Further study is needed to conclude the impact of these waves and its variations to the tidal energy resources.

\section{Conclusion}

Numerical modelling, conducted using Delft3D has shown it is capable of replicating the field data. Model downscaling using the domain decomposition method also results in a satisfying simulation. The velocity validation is not as smooth as the water level expected due to the sensitivity to the water depth. However, the validation is still deemed acceptable.

The Northern part of Lepar Strait induces a higher velocity due to shallower water and narrower channel. The flow is slower at the central and Southern parts due to the deeper and wider channels, respectively. Three potential sites are introduced, where the velocity is found to be over $1.5 \mathrm{~m} / \mathrm{s}$. The velocity reaches its peak at high and low tide while hitting the lowest velocity at slack water. The sites are shallow and the mean velocity is around $0.5 \mathrm{~m} / \mathrm{s}$. Thus, a GHT turbine with a horizontal position is used. In 2019, the annual theoretical power was between 1,017.68 and $2,436.94 \mathrm{kWh} / \mathrm{m}^{2}$. The power output is reduced to between 741.11 - 1,870.41 kWh annually, applying turbine limitations. The financial analysis needs to be conducted to determine project feasibility. Nevertheless, it is essential to study the impact of future tidal turbine farms, especially in very shallow water regions.

It is important to note that this study provides a first estimation of the tidal current power potential at Lepar Strait. Furthermore, a more in-depth hydrooceanographic survey (such as bathymetry, water level, and current velocity) is needed to produce a more accurate power estimation.

\section{Author Contribution}

Conceptualisation and funding, H.A.; Methodology, H.A. and M.B.P; Field campaign, H.A.; Modelling, M.B.P; Analysis, H.A. and M.B.P; Writing, H.A. and M.B.P. All authors have read and approved the published version of the manuscript.

\section{Acknowledgements}

This research was funded by the P3MI - Program Penelitian, Pengabdian kepada Masyarakat dan Inovasi ITB. The authors present gratitude to Deltares for providing the open-source modelling tool and BIG for the water level data.

\section{References}

Ajiwibowo, H., Lodiwa, K. S., Pratama, M. B., \& Wurjanto, A. (2017a). Field measurement and numerical modeling of tidal current in Larantuka Strait for renewable energy utilization. International Journal of GEOMATE, 13(39), 124-131. https://doi.org/10.21660/2017.39.98548

Ajiwibowo, H., Lodiwa, K. S., Pratama, M. B., \& Wurjanto, A. (2017b). Numerical model of tidal current for power harvesting in Bangka Strait. International Journal of Earth Sciences and Engineering, 10(04), 833-843. https://doi.org/10.21276/ijee.2017.10.0415

Ajiwibowo, H., \& Pratama, M. B. (2017). The effect of gate existence at L Island on the seabed profile due to reclamation of Jakarta Bay. International Journal of Engineering and Technology, 9(5), 3763-3774. https://doi.org/10.21817/ijet/2017/v9i5/170905110

Ajiwibowo, H., \& Pratama, M. B. (2018). The influence of the Jakarta bay reclamation on the surrounding tidal elevation and tidal current. International Journal of GEOMATE, 15(48), 55-65. https://doi.org/10.21660/2018.48.22773

Ajiwibowo, H., \& Pratama, M. B. (2020). Hydrodynamic changes impacted by the waterway capital dredging in Cikarang Bekasi Laut Channel, West Java, indonesia. Water Practice and Technology, 15(2), 450-459. https://doi.org/10.2166/wpt.2020.032

Ajiwibowo, H., Pratama, M. B., \& Wurjanto, A. (2017). Assessment of tidal current power potency in Kelabat Bay, Indonesia. International Journal of Engineering and Technology, 9(4), 3100-3110. https://doi.org/10.21817/ijet/2017/v9i4/170904089

Amiruddin, Ribal, A., Khaeruddin, \& Amir, K. A. (2019). Preliminary estimation of tidal current energy for three straits in the vicinity of Bali and Lombok Islands. International Journal of Renewable Energy Research, 9(4), 1638-1649. https://www.ijrernet.ijrer.org/index.php/ijrer/article/view/9910/pdf

Anwar, I. P., Putri, M. R., \& Setiawan, A. (2018). Variation of Volume Transport and Variability of Current in Karimata and Gaspar Straits during 2010-2014 Based on Numerical Modelling. Jurnal Ilmu Dan Teknologi Kelautan Tropis, 9(2), 771-780. https://doi.org/10.29244/jitkt.v9i2.19309

ASELI. (2014). Potensi Energi Laut Indonesia. Asosiasi Energi Laut Indonesia.

BIG. (2018). Batimetri Nasional. Seamless Digital Elevation Model (DEM) Dan Batimetri Nasional. http://tides.big.go.id/DEMNAS/

BIG. (2021). DATASET: indo_ww3 VARIABLE: Wave height (meter). http://tides.big.go.id/las/UI.vm

Bijvelds, M. (2001). Numerical modelling of estuarine flow over steep topography. Delft University of Technology.

BPS Kabupaten Bangka Selatan. (2020). Tukak Sadai Subdistrict in Figures. https://bangkaselatankab.bps.go.id/publication

de Pablo, H., Sobrinho, J., Garcia, M., Campuzano, F., Juliano, M., \& Neves, R. (2019). Validation of the 3D-MOHID Hydrodynamic Model for the Tagus Coastal Area. Water, 11(8), 1713. https://doi.org/10.3390/w11081713

Deltares. (2014). Delft3D-FLOW: User manual (3.15). Deltares.

DEN. (2019). Indonesia Energy Outlook 2019. https://www.esdm.go.id/assets/media/content/contentindonesia-energy-outlook-2019-english-version.pdf

ECMWF. (2021). ERA5 hourly data on single levels from 1979 to present. https://doi.org/10.24381/cds.adbb2d 47

Fajar, Purwanto, \& Indrayanti, E. (2014). Kajian potensi arus laut sebagai energi alternatif pembangkit listrik di perairan sekitar Jembatan Suramadu Selat Madura. 3(3), 294-303.

Firdaus, A. M., Houlsby, G. T., \& Adcock, T. A. A. (2019). Resource estimates in Lombok Straits, Indonesia. Proceedings of the 13th European Wave and Tidal Energy Conference, September, 1669.

Firdaus, A. M., Houlsby, G. T., \& Adcock, T. A. A. (2020). Tidal energy resource in Larantuka Strait, Indonesia. Energy, 173(2), 81-92. 
Garanovic, A. (2021, April 23). Orbital Marine launches world's most powerful tidal turbine. https://www.offshoreenergy.biz/orbital-marine-launches-worlds-most-powerfultidal-turbine/

GEBCO Bathymetric Compilation Group 2019. (2019). The GEBCO_2019 Grid - a continuous terrain model of the global oceans and land. British Oceanographic Data Centre. https://doi.org/10.5285/836f016a-33be-6ddc-e0536c86abc0788e

Gielen, D., Boshell, F., Saygin, D., Bazilian, M. D., Wagner, N., \& Gorini, R. (2019). The role of renewable energy in the global energy transformation. Energy Strategy Reviews, 24, 3850. https://doi.org/10.1016/j.esr.2019.01.006

Hariati, F., Ajiwibowo, H., Hadihardaja, I. K., \& Nugroho, J. (2019). Modeling Adaptation to Salinity Intrusion in Segara Anakan Estuary due to Sea Level Rise. International Journal of GEOMATE, 16, 2186-2990. https://doi.org/10.21660/2019.53.05655

Hartoko, A., Febrianto, A., Pamungkas, A., Fachruddin, I., \& Helmi, M. (2019). The Myth and Legend of Sadai and Gaspar Strait Bangka Belitung (Banca-Billiton) and Oceanographic Conditions. International Journal of GEOMATE, $\quad 17, \quad 212-218$. https://doi.org/10.21660/2019.62.93965

IRENA. (2017). Renewable Energy Prospects: Indonesia, a REmap analysis. International Renewable Energy Agency. www.irena.org/remap

Kurniawan, A., Barli, P. P. A., Pratama, M. B., \& Fitriadhy, A. (2021). Potential study of tidal stream turbine farm at Toyapakeh Strait. ILMU KELAUTAN: Indonesian Journal of Marine Sciences, In Review.

Lewis, M., Neill, S. P., Robins, P., Hashemi, M. R., \& Ward, S. (2017). Characteristics of the velocity profile at tidalstream energy sites. Renewable Energy, 114. https://doi.org/10.1016/j.renene.2017.03.096

Moomaw, W., Yamba, F., Kamimoto, M., Maurice, L., Nyboer, J., Urama, K., \& Weir, T. (2011). Introduction. In O. Edenhofer, Pichs-Madruga, R. Y. Sokona, K. Seyboth, P. Matschoss, S. Kadner, T. Zwickel, P. Eickemeier, G. Hansen, S. Schlömer, \& C. vo. Stechow (Eds.), IPCC Special Report on Renewable Energy Sources and Climate Change Mitigation (p. 48). Cambridge University Press.

Natalie, E., Ismanto, A., Priyono, B., Studi Oseanografi, P., Perikanan dan Ilmu Kelautan, F., \& Penelitian dan Observasi Laut Jl Baru Perancak, B. (2016). Analisis Karakteristik Arus Laut untuk Pemanfaatan Potensi Energi Alternatif di Perairan Selat Gaspar. In Jurnal Oseanografi (Vol. 5, Issue 3). Diponegoro University. http://ejournal-

s1.undip.ac.id/index.php/joseJl.Prof.Sudarto,SHTembalan gTlp./Fax.

Nederhoff, K., Dongeren, A. van, \& Ormondt, M. van. (2016). Delft Dashboard: a MATLAB- based rapid tool for setting up coastal and estuarine models. Deltares. https://publicwiki.deltares.nl/display/DDB/General

Neill, S. P., Vögler, A., Goward-Brown, A. J., Baston, S., Lewis, M. J., Gillibrand, P. A., Waldman, S., \& Woolf, D. K. (2017). The wave and tidal resource of Scotland. Renewable Energy, 114. https://doi.org/10.1016/j.renene.2017.03.027

Novico, F., Sudjono, E. H., Egon, A., Menier, D., Methew, M., \& Pratama, M. B. (2021). Tidal Current Energy Resources Assessment in the Patinti Strait, Indonesia. International Journal of Renewable Energy Development, 10(3), 517-525. https://doi.org/10.14710/ijred.2021.35003

Orhan, K., Mayerle, R., Narayanan, R., \& Pandoe, W. W. (2016). Investigation of the energy potential from tidal stream currents in Indonesia. Proceedings of the Coastal
Engineering Conference, 35(September https://doi.org/10.9753/icce.v35.management.10

2017).

Orhan, K., Mayerle, R., \& Pandoe, W. W. (2015). Assesment of Energy Production Potential from Tidal Stream Currents in Indonesia. Energy Procedia, 76, 7-16. https://doi.org/10.1016/j.egypro.2015.07.834

Pamungkas, A. (2018). Karakteristik Parameter Oseanografi (Pasang-Surut, Arus, dan Gelombang) di Perairan Utara dan Selatan Pulau Bangka. Buletin Oseanografi Marina, 7(1), 51. https://doi.org/10.14710/buloma.v7i1.19042

Pemerintah Kabupaten Bangka Selatan. (2018). Infrastruktur Kawasan Industri Sadai.

Pratama, M. B. (2017). Studi Potensi Daya Pembangkit Listrik Tenaga Arus Laut Selat Bangka, Provinsi Kepulauan Bangka Belitung. Institut Teknologi Bandung.

Pratama, M. B. (2020). Modelling Tidal Energy Extraction in Sunda Strait, Indonesia. The University of Edinburgh.

Pratama, M. B. (2019). Tidal flood in Pekalongan: Utilizing and operating open resources for modelling. IOP Conference Series: Materials Science and Engineering, 676(1), 012029. https://doi.org/10.1088/1757-899X/676/1/012029

Pratama, M. B., Venugopal, V., Ajiwibowo, H., Ginting, J. W., \& Novico, F. (2020). Modelling Tidal Flow Hydrodynamics of Sunda Strait, Indonesia. ILMU KELAUTAN: Indonesian Journal of Marine Sciences, 25(4), 165-172. https://doi.org/10.14710/ik.ijms.25.4.165-172

Rahman, A., \& Venugopal, V. (2017). Parametric analysis of three dimensional flow models applied to tidal energy sites in Scotland. Estuarine, Coastal and Shelf Science, 189, 17-32. https://doi.org/10.1016/j.ecss.2017.02.027

Ritchie, H. (2017). Renewable Energy. OurWorldInData.Org. https://ourworldindata.org/renewable-energy

Rizal, A. M., Ningsih, N. S., Sofian, I., Hanifah, F., \& Hilmi, I. (2019). Preliminary study of wave energy resource assessment and its seasonal variation along the southern coasts of Java, Bali, and Nusa Tenggara waters. Journal of Renewable and Sustainable Energy, 11(1), 014502. https://doi.org/10.1063/1.5034161

Sartika, D., Hartoko, A., \& Kurniawan, K. (2018). Analisis Data Batimetri Lapangan dan Citra Landsar 8 OLI di Perairan Selat Lepar, Kabupaten Bangka Selatan. SAINTEK PERIKANAN: Indonesian Journal of Fisheries Science $\begin{array}{lll}\text { and Technology, } & \text { 13(2), }\end{array}$ https://doi.org/10.14710/ijfst.13.2.75-81

Sippa Cipta Karya. (2017). Rencana Program Investasi Jangka Menengah Kabupaten Bangka Selatan. https://sippa.ciptakarya.pu.go.id/sippa_online/ws_file/dok umen/rpi2jm/DOCRPIJM_e6a506b29c_BAB IIBAB 2.pdf

Takagi, H., Pratama, M. B., Kurobe, S., Esteban, M., Aránguiz, R., \& Ke, B. (2019). Analysis of generation and arrival time of landslide tsunami to Palu City due to the 2018 Sulawesi earthquake. Landslides, 16, 983-991. https://doi.org/10.1007/s10346-019-01166-y

Uihlein, A., \& Magagna, D. (2016). Wave and tidal current energy - A review of the current state of research beyond technology. In Renewable and Sustainable Energy Reviews (Vol. 58, pp. 1070-1081). Elsevier Ltd. https://doi.org/10.1016/j.rser.2015.12.284

Visit Bangka Belitung. (2017). Bab 4 Kondisi Umum Wilayah Provinsi Kepulauan Bangka Belitung. http://www.visitbangkabelitung.com/public/file/download/ BAB_IV_-_VII.pdf

Wolanski, E., \& Elliott, M. (2016). Estuarine water circulation. In Estuarine Ecohydrology (pp. 35-76). Elsevier. https://doi.org/10.1016/b978-0-444-63398-9.00002-7 